\title{
DIE DEPARTEMENT OU TESTAMENT, 'N HALWE EEU
}

\author{
J H LE ROUX
}

\begin{abstract}
The department of Old Testament, fifty years

The department of Old Testament (Section B) at the University of Pretoria is celebrating its fiftieth year. At the beginning of 1938 the faculty opened with four professors and six students. This article briefly investigates the contribution of four professors who taught the Old Testament. As a rather conservative theologian $\mathrm{J} \mathrm{H}$ Kritzinger strongly emphasized the importance of a scientific approach to Old Testament and of sound exegetical study. $\mathrm{He}$ was succeeded by $\mathrm{A} \mathrm{H}$ van $\mathrm{Z} y \mathrm{l}$ who had a more historical approach to the Old Testament, took the historical critical method seriously and made its results useful to the church. WS Prinsloo focussed on the text as we have it today and paid much attention to its structure by means of syntactical analysis. To a certain extent $W$ Vosloo continued the line of Van Zyl and Prinsloo: he emphasized the importance of a historical approach, but also investigated the structure of a text to determine its theology.
\end{abstract}

Vanjaar is die departement Ou Testament van die Ned Geref Kerk aan die Universiteit van Pretoria vyftig jaar oud. Aan die begin van 1938 het die teologiese fakulteit van die Ned Geref Kerk nederig met vier dosente en ses studente begin. Die aanvangsjare was maar moeilik met ontoereikende lesinglokale, 'n teologiese biblioteek wat opgebou moes word en talle dringende sake waaraan aandag gegee moes word. Belangrik was dat ' $n$ teologiese tradisie gevestig moes word aan die hand waarvan die studente as predikante van die kerk opgelei kon word. In hierdie eerste jare het die kerk besluite geneem wat vir die bestudering van die Ou Testament van groot waarde was. Een so 'n besluit was dat die kerk onder geen omstandighede van Hebreeus as toelating vir die Ou-Testamentiese studie sou afsien nie en dat hoë akademiese standaarde te alle tye gehandhaaf moes word. Van die begin af moes teologiese studie aan streng wetenskaplike vereistes voldoen. Die skepping van 'n selfstandige departement Ou Testament en die feit dat dit nie saam met Nuwe Testament in byvoorbeeld ' $n$ departement Bybelkunde verenig is nie, was ' $n$ stap wat nie oorbeklemtoon kan word nie. Hiermee is gesê dat die kerk die studie van die Ou Testament van sentrale belang ag omdat die kerk uit dié boek leef. Deur die jare is ' $n$ stewige grondslag vir die beoefening van die Ou-Testamentiese wetenskap gelê. 'n Bepaalde benadering tot en 
omgang met die Ou Testament het mettergaan gevestig geraak. Studente is vanuit hierdie perspektiewe op die Ou Testament gevorm en tot vandag toe pluk die kerk die vrug daarvan. Hieronder wil ons aan die hand van vier $\mathrm{Ou}$ Testament dosente iets van hierdie soort benadering tot die Ou Testament verduidelik. Die persone na wie verwys gaan word, is professore $\mathrm{J} \mathrm{H}$ Kritzinger, A H van Zyl, W S Prinsloo en W Vosloo. Elkeen het van die gesag van die Woord en die belydenis van die kerk uitgegaan, maar het ooreenkomstig eie insigte inhoud aan die OuTestamentiese wetenskap gegee.

\section{1. $\mathrm{J} H$ Kritzinger: die eerste professor in die Ou Testament}

Johan Hendrik Kritzinger is in 1905 gebore. Sy ouers was "innig vrome mense". ' By bidure het sy vader dikwels voorgegaan en sy moeder het die gemeentesang gelei. In hierdie vrome konteks het die jong Kritzinger opgegroei en dit het sy lewe en teologie beslissend beïnvloed. Vanaf 'n baie jong ouderdom het hy die begeerte gehad om predikant te word. In 1929 het hy hom dan ook by die Kweekskool in Stellenbosch aangesluit. As student het hy goed gepresteer en ' $n$ beurs verwerf om in Nederland vir die doktorsgraad te gaan studeer.

Aan die Vrije Universiteit van Amsterdam was Van Gelderen sy promotor. Van Gelderen het baie aandag aan die student uit Suid-Afrika bestee en op 'n stadium selfs ekstra klasse in Babilonies-Assiriese spykerskrif gegee. Ook Aalders sou hom "geestelik en intellektueel" verryk. ${ }^{2}$ Alles het voorspoedig verloop sodat Kritzinger op Vrydag 8 Februarie 1935 met sukses sy proefskrif, "Die profesie van Joël", kon verdedig. Sy Nederlandse verblyf en die vormende wetenskaplike invloed, het Kritzinger so gunstig ervaar dat hy in een van die stellings aan die einde van sy proefskrif verklaar dat die Ned. Geref. Kerk nie promosiegeleenthede in Suid-Afrika moet skep nie, maar "aspirant promovendi" eerder aanmoedig om "op die Europese vasteland te promoveer". 3

Terug in Suid-Afrika het Kritzinger geen beroep ontvang nie. 'n Sterk moontlikheid het bestaan dat 'n Oos-Kaapse gemeente hom sou beroep, maar het na bewerings van sy moontlike simpatie met Du Plessis van dié plan afgesien. Die grond vir hierdie bewering was tweërlei. In die voorwoord tot sy proefskrif het Kritzinger Du Plessis opsigtelik meer as die ander dosente op Stellenbosch bedank. Van Du Plessis word gesê dat hy deur sy deeglikheid en sy helderheid by Kritzinger " $n$ besondere belangstelling in hierdie (Hebreeuse) taal gewek" het.. Aan die einde van sy proefskrif in een van sy stellinge ondersteun hy Du Plessis se kritiek teen die vertalers van die Afrikaanse Bybel in verband met die 
gebruik van die Textus Receptus. Volgens Du Plessis was die gebruik hiervan 'n miskenning van die "hele studie van die N.T. sedert 1550 en sal die ondersoek oor die N.T. deur ons volk vir ' $n$ hele geslag of meer agteruitsit". ${ }^{5}$ Volgens Kritzinger het die professore aan die Kweekskool sy proefskrif gunstig ontvang en selfs verklaar dat "wat regsinnigheid in die leer betref, (dit) bo alle verdenking staan". ${ }^{6}$ Een van die professore het egter in ' $n$ artikel gemeen dat vanweë die opmerkings oor Du Plessis Kritzinger "modernistiese neigings" vertoon en so is 'n etiket van "modernisme" om hom gehang. Hierdie uitlatings het egter daartoe gelei dat hy die Oos-Kaapse beroep nie ontvang het nie. Hierdie insident is nogal baie duidelik. Veral die dertigerjare het nog die nawerking van die Du Plessisstryd sterk gevoel. Mense is onder verdenking geplaas en alles is gedoen om enige moontlike invloed van Du Plessis die nek in te siaan. Selfs die stigting van ' $n$ teologiese fakulteit in Pretoria het sommige met die Du Plessisstryd in verband gebring. Dit het daartoe gelei dat in die beginjare daaraan getwyfel is of die fakulteit die vertroue van die kerk in al die provinsies geniet. Op die een of ander manier het die invloed van Du Plessis tog 'n skaduwee oor die fakulteit gegooi. Soos aanstons nog sal blyk, was Kritzinger geensins 'n aanhanger van Du Plessis nie. Hy het net die goeie van sy ou leermeester oorgeneem en daarbenewens 'n groot bewondering vir hom as mens gekoester. Kritzinger was eerder daarop bedag om nie die ou strydvure aan te blaas nie en om die eenheid in die fakulteit te bewaar. Eenheid het hom na aan die hart gelê en hy het hom saam met sy kollegas hiervoor beywer. ${ }^{7}$ Dit was

"sy strewe om steeds die vrede te handhaaf by alle verskil van mening wat hom mag voordoen". 8

Kritzinger het hom met alle kragte aan sy vak gewy. Sy kollegas het hom hoog geag vir sy vakkennis en die besondere wyse waarop hy die vak beoefen het. Die Ou-Testamentiese wetenskap is ' $n$ vakgebied wat "so kwistig besaai is met allerlei leerstellige voetangels en klemme", maar Kritzinger het "as die bewaarder van die regsinnigheid en die teenstander van die dwaling" daarin geslaag om die vak op 'n bestendige koers te plaas. ${ }^{9}$ Kostelik is dat Kritzinger aan die einde van sy akademiese loopbaan die Here dank dat hy nooit in 'n kerkstryd of leerstryd beland het nie. Aan die beoefening van die Ou-Testamentiese wetenskap is daar soveel probleme verbonde en juis daarom is hy so dankbaar dat dit tot geen probleme in die kerk aanleiding gegee het nie. ${ }^{10}$

Van Kritzinger is gesê dat hy die vermoë verstaan het om ' $n$ liefde vir sy vak by sy studente aan te kweek." Dit blyk ook telkens uit gesprekke met oudstudente van Kritzinger dat hy 'n groot indruk op hulle gemaak het. By sy aftrede dank die professor ook die studente vir hulle gesindheid teenoor hom. Vir die ongeveer twee honderd en vyftig stu- 
dente wat by hom klas gehad het, het hy net lof. Hulle het hom met eerbied en respek behandel al het hulle van hom verskil. Dit het so ' $n$ indruk op hom gemaak dat hy die wens uitspreek dat hulle altyd met waardigheid en beskeidenheid in hulle gemeentes sal optree. ${ }^{12}$

Kritzinger se akademiese loopbaan is gekenmerk deur siekte. In 1948 het hy op die ouderdom van drie en veertig koronêre trombose gehad. Dit het veroorsaak dat hy sy aktiwiteite moes inkort en "sy leefwyse streng in ag moes neem". ${ }^{13}$ Elf jaar later het hy 'n nog erger hartaanval gehad en die medici het gemeen dat dit die einde van sy lewe sou wees. Weer eens het hy dit oorleef, maar dit het veroorsaak dat hy op sestigjarige leeftyd moes aftree. Tans is Kritzinger drie en tagtig jaar oud en hy en sy vrou geniet albei redelike gesondheid.

Vanweë Kritzinger se siekte kon hy uiteraard nie soveel skryf nie, maar het nogtans deur die manier waarop hy die wetenskap bedryf en aangebied het, ' $n$ besondere bydrae tot die onderrig van die Ou Testament aan die Universiteit van Pretoria gelewer. Hy was 'n regsinnige geleerde en het op sy eie manier en ooreenkomstig die wetenskaplike eise van sy tyd inhoud hieraan verleen. Met baie groot eerbied en piëteit sou ons hom 'n tipiese voorbeeld van 'n Ou-Testamentikus in die Ned Geref Kerk gedurende die najare van die Du Plessisstryd kon noem. Kritzinger se onderrig en vakbemoeienis was dus breedweg konserwatief en dit het 'n aantal besliste kenmerke vertoon. In die eerste plek was hy 'n wetenskapsmens: Baie hoë akademiese standaarde is gestel en die Ou-Testamentiese studie moes so gedoen word dat op wetenskaplikheid aangedring kon word. Vervolgens was sy teologie in die geestelike tradisies van die Ned Geref Kerk gedrenk: Die Ou-Testamentiese wetenskap kon nie los van ' $n$ vrome lewenswandel ('n ryke gebedslewe, ' $n$ heilige lewenswandel) beoefen word nie en die kerk se verkondiging moes deur die wetenskap gedien word. ' $n$ Derde kenmerk is dat die Ou-Testamentiese wetenskap binne die gereformeerde belydenis verdiskonteer moes word. 'n Spesifieke teksteorie, wat die gevolg van voorafgaande was, was 'n volgende kenmerk van Kritzinger se wetenskapsbeoefening: Die Ou Testament het gesag, vorm 'n eenheid en in die eksegese moes daarmee rekening gehou word. Nog 'n kenmerk was die rol wat die Nuwe Testament gespeel het: Alhoewel die Ou Testament nie doelbewus vanuit die Nuwe Testament gelees moes word nie, het dit tog 'n belangrike verstaansfunksie vervul. ' $n$ Belangrike kenmerk van Kritzinger se werk, is die sterk historiese inslag daarvan: In sy geval het dit beteken dat die Ou Testament historiese feite bevat aangaande gebeurtenisse wat werklik plaasgevind het, dat dit deur gewyde skrywers opgeteken is, ${ }^{14}$ dat die geskrifte van die Ou Testament so vroeg as moontlik gedateer moes word en waar die historisiteit in die gedrang gebring is, is 
die Skrifgesag aangetas. ${ }^{15}$ Nog 'n kenmerk is dat Kritzinger hom graag by "behoudende Skrifverklaarders" ${ }^{16}$ gevoeg het: Hy was goed met die "radikaal-kritiese" werke" van persone soos Wellhausen en Gunkel bekend, maar vind onder geen omstandighede by hulle aansluiting nie. 'n Laaste, maar sekerlik die belangrikste kenmerk van Kritzinger se arbeid, is die klem op eksegese: Alhoewel metodologiese refleksie nie eintlik voorgekom het nie en eksegese eintlik aan die hand van sekondêre werke gedoen is, het die eksegetiese arbeid volgens Kritzinger die belangrikste element van die studie van die Ou Testament uitgemaak. Enkele van hierdie kenmerke kan ons aan die hand van sy werk oor die boek Joël illustreer.

Getrou aan sy konserwatiewe aanpak begin hy sy werk oor die profeet Joël met 'n historiese fundering. Sonder meer word die historisiteit van die profeet aanvaar en word hy as die skrywer van die boek beskou. Enige moontlikheid dat die naam "Joël" simbolies gebruik is of bloot 'n pseudoniem was, is vir hom "heeltemal onmoontlik". ${ }^{18}$ Ten opsigte van die datering sluit hy by konserwatiewe geleerdes soos Keil, Delitzsch, Ridderbos en Van Gelderen aan en verklaar: "ek is van oordeel dat wat later ingebring is teen ' $n$ voor-eksiliese datering (en wel onder koning Joas tydens sy minderjarigheid) nie genoegsaam is om hierdie standpunt prys te gee nie". ${ }^{19}$ Hierdie siening is gegrond op wat Credner in 1831 daaroor gesê het. Aangesien hierdie vroeë datering vir hom belangrik is, is dit interessant om te sien hoe hy die stof hanteer sodat dit by sy siening inpas. ${ }^{20}$ Die feit dat Joël geen melding van 'n koning maak nie, word dikwels as grond vir 'n na-eksiliese datering beskou, maar volgens Kritzinger kon dit ook goedskiks na die tyd, toe die hoëprister namens die minderjarige koning Joas regeer het, verwys. Nog 'n moontlike na-ballingskapse verwysing is die feit dat Joël geen spesifieke sondes vermeld nie, maar Kritzinger meen dit kon ook aan die hervorminge van die hoëpriester, toe hy in die plek van die minderjarige koning regeer het, te wyte wees. Sommige het ook beweer dat Joël bepaalde apokaliptiese kenmerke vertoon en daarom na-eksilies moes wees, maar Kritzinger lê so 'n norm vir apokaliptiek aan dat die boek "ver ... te kort skiet" 21 en die voor-eksiliese datering behou kan word. Voorbeelde kan vermeerder word, om Kritzinger se historiese bemoeienis aan te toon; daardeur wou hy die historisiteit van die gebeure bevestig en 'n vroeë datering van die Ou-Testamentiese geskrifte verseker.

In sy eksegese maak hy groot moeite met die teks. Met behulp van kommentare stoei hy met al die probleme, maar vertoon 'n geneigdheid om op die ou einde met die konserwatiewe geleerdes te konkludeer. Dit beteken hoegenaamd nie dat Kritzinger 'n blote naprater was en geen selfstandige siening gehad het nie. Hy het krities met hulle omgegaan. 
Die een oomblik kon hy met Ridderbos, Aalders, Van Gelderen, Keil en ander behoudende geleerdes saamstem, maar dan kon hy ook weer heftig van hulle verskil. Ons sou egter kon beweer dat hy geestelik en teologies so nou by hierdie geleerdes aangesluit het dat hulle sy eksegetiese bril geslyp het. So byvoorbeeld is daar volgens Kritzinger meer as een manier waarop die eerste twee hoofstukke van die boek Joël gelees kan word: Die allegoriese, die apokaliptiese en die realistiese. Ooreenkomstig sy konserwatiewe vertrekpunt is daar slegs een moontlikheid: "Uit dit alles blyk dat die enige juiste opvatting van die sprinkane die realistiese is." 22

Interessant is ook hoe Nuwe-Testamentiese perspektiewe in die eksegese meespeel: Die "dag van die Here" in 1:15 word nie soseer binne Ou-Testamentiese konteks verstaan nie, want soos in die res van die Ou Testament is elke gerig (in hierdie geval die sprinkane) slegs 'n voorloper van die eintlike dag van die Here wat in al sy volheid eers aan die einde van hierdie bedeling sal aanbreek; ${ }^{23}$ die vermelding van die uitstorting van die Gees in 2:28-29 sal eers in die verre toekoms plaasvind: "Petrus het dan ook tereg hierdie woorde opgevat as in die laaste dae" ${ }^{\prime 2}$ in 2:30-31 word sekere tekens van die dag van die Here geskets wat voorlopig eers tydens ' $n$ geleentheid soos die val van Jerusalem in 70 $\mathrm{n} \mathrm{C}$ vervul word, maar wat aan die einde van hierdie bedeling tydens die wêreldgerig finaal vervul sal word; ${ }^{25}$ in $3: 1-3$ word melding van die verandering van Juda se lot gemaak en volgens Kritzinger "slaan dit op ... die hele verlossingsproses tot by die wederkoms van Christus" ${ }^{26}$

Ons kan Kritzinger dus samevattend beskryf as iemand wat die beoefening van die Ou-Testamentiese wetenskap binne ' $n$ behoudende konteks wou plaas.

\section{A H van $Z y l$}

Aangesien ek in ' $\mathrm{n}$ ander artikel ("A $\mathrm{H}$ van $\mathrm{Zyl}$ as Ou-Testamentikus") wat binnekort verskyn meer volledig oor die bydrae van Van $Z$ Yl geskryf het, word hier net op een aspek van sy werk gewys: Sy hantering van die historiese kritiese metode en die resultate daarvan met betrekking tot die ontstaan van die voorgeskiedenis (Gen 1-11). Van Zyl, die opvolger van Kritzinger, het hiermee iets bewerkstellig wat vroeër dalk nie moontlik was nie. Hy het besef dat die bydraes van die historiese kritiek nie geignoreer of op ' $n$ fundamentalistiese wyse weggeredeneer kan word nie. Hierdie benadering het belangrike insigte meegebring en hy wou dit vir die kerk vrugbaar maak. Om sy doel te kon bereik, moes hy die kritiese angel uit die Pentateugkritiek neem en dit as't ware ombou en aanpas dat dit vir ons aanvaarbaar sal wees. In die onderstaande voorbeeld word 
duidelik getoon hoe hy dit bewerkstellig het.

Dit is belangrik om daarop te let dat Van Zyl die teks in sy finale vorm as wegspringplek gebruik. Ten opsigte van die voorgeskiedenis (Gen 1-11) blyk die literêre kritiek se onderskeidinge geheel en al ontoereikend te wees. Meer word bereik indien die finale gestalte as beginpunt geneem, slegs met een finale outeur gewerk en die ontstaansgeskiedenis slegs as bydraend tot die verstaan van die eindproduk beskou word. ${ }^{27}$ Die finale outeur van die voorgeskiedenis het vertellinge wat op verskillende plekke en tye ontstaan het, geneem en dit tot een groot eenheid saamgesnoer. ${ }^{28}$ Van Zyl illustreer sy siening met die volgende beeld:

In ons kinderdae het ons lang swepe met kort biesies gevleg. Net voordat die einde van die vorige biesie bereik is, is die nuwe biesie saam met die vorige ingevleg om dit stewig te las ... selfs al kon 'n mens die lasplek onderskei. Tog is dit moeilik om te sê waar begin die nuwe en waar eindig die vorige. Hier (dws in die voorgeskiedenis) is dit ook die geval en vorentoe kom ' $n$ mens weer eens hierdie invlegmetode van die finale outeur tee. ${ }^{29}$

Die eerste biesie wat die finale outeur van die voorgeskiedenis geneem het, was die skeppingsverhaal (Gen 1:1-2:3). Waar hierdie kunstige stuk prosa ontstaan het, is onseker. Heel waarskynlik het dit in ' $n$ tempel of ' $n$ heiligdom ontstaan en het priesters eerste gestalte daar ${ }^{+}$ aan gegee. ${ }^{30}$

Genesis $2: 4-3: 24$ is die tweede biesie wat die skrywer geneem het. Belangrik is dat Van Zyl dit nie as nog 'n skeppingsverhaal beskou nie, maar dit 'n tuinverhaal noem. Hy merk tereg op dat hierdie biesie heelwat verskil van die vorige een ten opsigte van vorm en styl. Ook die oogmerk van laasgenoemde is verskillend, want dit fokus op die mens se sonde en ellende. Anders as die skeppingsverhaal vertoon die tuinverhaal ' $n$ besliste boerderybelangstelling. Sommige praat dan ook daarvan as ' $n$ boereverhaal. Hieruit sou ' $n$ mens kon konkludeer dat dit ook in ' $n$ totaal ander ontstaansoord vorm en beslag gekry het as die skeppingsverhaal. Veral word gedink aan 'n profetiese kring aangesien daar tog ook profete uit 'n boeregemeenskap afkomstig was en die tuinverhaal ook ooreenkomste toon met die profetiese prediking. Die finale outeur het hierdie biesie by die skeppingsverhaal gevoeg om aan te toon wat van die eerste mense geword het.

'n Ander biesie, die verhaal van Kain in Genesis 4:1-26, is gebruik om die verdere verloop van die mensdom na die sondeval te beskryf. Die skrywer laat die verhaal netjies by die voorafgaande aansluit: Hy vertel van kindergeboortes na die voorafgaande tragedie, die uitbreiding van 
die sonde en die kultuurtaak wat die mens volvoer deur verskillende beroepe te beoefen. Die landboukundige belangstelling van hierdie gedeelte koppel dit aan die voorafgaande. ${ }^{31}$

Aangesien die omstandighede van die mensdom vanweë die sonde versieg, neem die finale skrywer ' $n$ interessante biesie (Gen 5:1-32), 'n geslagsregister, om daarmee troos te bring. Heel waarskynlik was dit 'n ou volksoorlewering wat mettergaan sy weg na 'n tempelargief gevind het en daar deur die finale skrywer aangetref is. Met hierdie ou geslagsregister in Genesis 5:1-32 wou hy die mense hoop gee en daarom plaas hy dit toe net na die verhaal van Kain en sy nageslag. Sodoende word dir ' $n$ waarborg vir toekomstige geslagte dat Jahwe sy seën in Genesis 1:28 gestand sal doen en dat die menslike geslag sal vermeerder. ${ }^{32}$

'n Uiters problematiese biesie vind ons in Genesis 6:1-4 waar van die hemelwesens wat met die vroue van die mens getrou het, vertel word. Hierdie biesie "wat die grens na die mitologiese byna oorsteek ... en met die een voet in die mitologie staan", het die finale outeur met die voorafgaande versmelt om die toenemende goddeloosheid te illustreer. ${ }^{33}$ Hierdie stuk "mite" het in die kerk al heelwat probleme veroorsaak en angsvallig is talle argumente aangevoer waarin die band met die mitologie heftig ontken is. Die probleem verkry' $n$ ander dimensie indien ons dit beskou as 'n stuk "mitologie" wat aangewend is om 'n bepaalde boodskap te illustreer.

'n Belangrike biesie in die verhaal van die voorgeskiedenis is die sondvloedverhaal in Genesis 6:5-9:29. Interessant is dat Van Zyl volgens sy werkmetode tot die konklusie kom dat die verhaalkompleks in Genesis 2:4-4:26 nie met die sondvloed bekend was nie en dat die twee aanvanklik in verskillende ontstaansoorde tot stand gekom en gefunksioneer het. Hy sien egter groot ooreenkomste tussen die sondvloed- en skeppingsverhale en meen dat albei in dieselfde kringe ontstaan het.

Om die voorgeskiedenis af te sluit, het die skrywer drie ander biesies gebruik. Die een is weer 'n geslagsregister en afkomstig uit die tempelargiewe. Vernuftig het die finale outeur die geslagsregister in Genesis 10:1 - 32 aan die voorafgaande sondvloedverhaal gekoppel en verkry dit dieselfde funksie as die ander geslagsregisters wat telkens verstrek word wanneer die moontlikheid van vermeerdering (vgl Gen 1:28) bedreig word. Toe Kain vir Abel doodgemaak het en moes vlug vir sy medemens, het die moontlikheid van uitbreiding uitsigloos voorgekom. Toe is Set gebore en volg ' $n$ geslagsregister (Gen 5:1-32) om te verklaar dat Jahwe se seën nog van krag is. ' $n$ Soortgelyke situasie het ons na die sondvloed: Noag en sewe ander het dit oorleef, hulle ontvang weer die belofte van getalsuitbreiding, die vervulling waarvan vir die leser bra onwaarskynlik lyk, maar dan vleg die skrywer die geslagsregisterbiesie 
juis op hierdie plek in om die trou van Jahwe te illustreer. Om die hoogtepunt van die mens se goddeloosheid te beskryf, gebruik hy 'n biesie wat met die familie van Abraham die land binnegekom het, te wete die verhaal van die toring van Babel (Gen 11:1-9). Die laaste biesie wat hy in die voorgeskiedenis invleg, is die geslagsregister van Sem. Daarmee wou hy weer eens aantoon dat Jahwe sy werk ongeag die sonde van die mens voortsit en ook die band met die daaropvolgende verhaalkompleks oor die aartsvaders bewerkstllig. ${ }^{34}$

So dan het die finale skrywer baie biesies wat op verskillende plekke ontstaan en gefunksioneer het, in 'n geheelwerk verenig. Van Zyl vat dit soos volg saam:

En al het daar talle meegewerk aan die voorgeskiedenis van hierdie oorlewering, het dit in sy finale vorm ' $n$ heel besondere beslag gekry danksy die skeppende vermoë van die eindskrywer of outeur wat nie net ' $n$ blote redakteur was wat los tradisies aanmekaar geryg het nie. Hy kan in die volste sin van die woord 'n geïnspireerde skrywer genoem word, omdat dit nou alreeds blyk dat hy'n eie bydrae in Gen. 1-11 gelewer het. ${ }^{35}$

In hierdie voorbeeld is die invloed van die Pentateugkritiek duidelik: Moses word nie as outeur aanvaar nie, met 'n lang ontstaanstyd word gereken, stof van diverse herkoms is gebruik, ensovoorts. Hy verpak hierdie kritiese insigte egter sodanig dat die skokeffek daarvan verminder word. Op hierdie manier het hy sy studente en die kerk die waarde van die historiese kritiek geleer sodat dit onbevange gebruik kon word. Van Zyl het ons 'n groot guns bewys en hy verdien ons dank daarvoor.

\section{W S Prinsloo}

Willem Sterrenberg Prinsloo is op 19 Augustus 1944 te Vrede gebore. Aan die begin van 1963 skryf hy in as student aan die Universiteit van Pretoria. Hy was 'n briljante student en het al sy grade met lof behaal. Vanaf 1971 is hy predikant van die kerk op Standerton totdat hy in 1974 as dosent beroep is. Hy aanvaar diens op 1 Januarie 1975 eers as lektor en later as professor. Aangesien Prinsloo buitelandse kontak vir die beoefening van die vak hoog geag het, het hy reeds 'n groot aantal internasionale vakkongresse bygewoon waar telkens referate gelewer is en het hy ook persoonlike verhoudings met belangrike Ou-Testamentici opgebou. Hy is ' $n$ beurshouer van die gesogte Alexander von Humboldstigting wat hom in staat gestel het om gedurende 1982/83 aan die Universiteit van Tübingen te studeer. Prinsloo het ook al ' $n$ hele aantal werke 
in plaaslike en internasionale tydskrifte gepubliseer. Vir die doeleindes van hierdie artikel vestig ons veral die aandag op sy boek oor Joël wat in ' $n$ internasionale reeks verskyn het. Dit het presies vyftig jaar na die werk van Kritzinger die lig gesien en toon duidelik hoe die wetenskap sedert die dertigerjare ontwikkel het.

In aansluiting by sy voorgangers vorm eksegetiese arbeid ook ' $n$ belangrike aspek van Prinsloo se werk. By hom is daar egter ' $n$ veel groter metodologiese refleksie en sy werk moet ook in terme van doelbewuste hermeneutiese en eksegetiese keuses verstaan word. So is dit 'n tipiese kenmerk van Prinsloo om op die teks in sy eindgestalte te konsentreer. Die teks soos hy nou voor ons lè, vorm die fokuspunt van sy eksegetiese bemoeiinge en die vertrekpunt van sy Ou-Testamentiese studie. Hierdie bewuste keuse is die resultaat van intensiewe navorsing oor hermeneutiek en eksegetiese metodiek. Die boek Joël is dus doelbewus vanuit hierdie perspektief benader. Gedurende sy verblyf in WesDuitsland as ' $n$ Alexander von Humboldt-beurshouer het hy ' $n$ deeglike studie van die navorsingsgeskiedenis in verband met Joël onderneem. Hiervolgens blyk dat die historiese kritiek die finale vorm van die boek misgekyk en eerder op die groei daarvan gelet het. 'n Belangrike eksponent hiervan is Bernhard Duhm. Op tipies literêr-kritiese manier is die boek Joël "afgeskil" totdat 'n "Urschrift" verkry is. Verder het Duhm gemeen dat slegs die eerste twee hoofstukke van die boek deur die profeet Joël geskryf kon gewees het terwyl die res van die hand van ' $n$ priester met ' $n$ apokaliptiese perspektief uit Makkabeërtyd is. Hierdie soort benadering het tot allerlei uiterstes gelei waarin vier tot vyf verskillende redaksies onderskei is. ${ }^{36}$ Hierteen het Prinsloo hom heftig verset en hom deel van ' $n$ beweging gevoel wat die eenheid van die boek Joël beklemtoon. ${ }^{37}$ In die geval van Prinsloo is dit nie maar ' $n$ toevallige keuse nie, maar hang dit saam met ' $n$ bepaalde teksteorie of perspektief op die teks. Anders as by die historiese kritiek waar die "nate" in die teks raakgesien en die oorspronge daarvan nagespeur word, "sien" Prinsloo net die finale vorm van die teks in sy eenheidsgestalte raak. Vanaf hierdie eindvorm begin hy dan werk om die boek in sy huidige gestalte, in sy geheel en as ' $n$ eenheid te bestudeer; verder word die relasie van die verskillende perikope tot mekaar bepaal en word die betekenis van elke individuele perikoop in die lig van die geheel bepaal. Met instemming beaam hy die woorde van Childs: "The crucial issue turns on how one reads the book in its present form." 38 Geen sprake dus van 'n terugwerk na die kleinste tekseenheid, sy historiese konteks en die groei daarvan nie. In die plek daarvan word alle aandag op die teks in sy eindgestalte gefokus. Die romantiese siening van die histories-kritici dat die oudste teks die gesaghebbende is en dat geen steen onaangeroer gelaat moet word om dit vas 
te stel nie, is "vervang" met 'n totaal nuwe visie op die teks. Die gesag van 'n boek hang tog nie van die soeke na die "Urschrift" af nie. Trouens, so 'n oorspronklik gerekonstrueerde teks is "vir ons van geen wesentlike belang nie". ${ }^{39}$ Waarom dit gaan, is die boek soos dit tans daar uitsien en die boodskap wat in hierdie finale vorm vasgestel moet word.

So 'n teksbenadering "benodig" 'n dienooreenkomstige eksegetiese metode. En in "hierdie opsig het die teksimmanente eksegese 'n belangrike funksie om te vervul". ${ }^{40}$ Ons kan dit nog nader bepaal: Die struktuuranalise is daardie metode wat aan die teks in sy finale vorm reg laat geskied. Hy stel dit soos volg: "The exegetical process must start synchronically. After all, one can only begin with the text as it stands. The content of a demarcated text can be established by means of structural analysis ... It does mean ... that structural analysis should be applied according to objective, formal, syntactical criteria. The structure exposed in this way will provide an objective framework which permits both content and historical aspects to feature." 41 Prinsloo se werkswyse het ' $n$ bepaalde woordeskat meegebring wat part en deel van talle studente se teologiese taal gevorm het: Begrippe soos "sinkronie" en "diakronie" het nou uiters belangrik geword, nou is die "teks as outonome gegewe" beskou, is die metode van struktuuranalise se "wetenskaplike verantwoordbaarheid en objektiwiteit" 42 beklemtoon, is veel van die "gekontroleerde invalshoek" gemaak, ${ }^{43}$, ensovoorts. Elkeen van hierdie woorde of uitdrukkings het net een gedagte gekommunikeer: Die finale vorm van die teks is die fokuspunt van die struktuuranalitiese eksegese. Hierdie siening van Prinsloo is gevorm deur die ontwikkelinge op die gebied van die taalkunde en die literatuurwetenskap. Van Ferdinand de Saussure het hy oorgeneem dat taal gestruktureerd is, dit wil sê 'n samehangende geheel vorm, en dat sinkroniese aspekte voorrang moet geniet en daarom moet die eksegese op 'n sinkroniese wyse begin. ${ }^{44}$

Dit is veral op die gebied van die eksegese dat Prinsloo sy grootste bydrae lewer. Veral sy werk oor die Psalms is uitstaande en in ' $n$ latere artikel sal ons hierby stilstaan. Hy het die eksegese as sy spesialiseringsgebied aanvaar en verskillende metodes beproef. Gedurende die Europese winter van 1978/79 het hy 'n groot aantal Engelse, Nederlandse en Duitse Ou-Testamentici besoek en pertinente probleemgebiede in die eksegese met hulle bespreek. ${ }^{45}$ By Prinsloo verloop die eksegetiese proses gewoonlik volgens dieselfde orde. Eers word die gedeelte afgebaken en tekskritiese vrae beantwoord. Met die analise van 'n struktuur is hy op sy beste. Aan die hand van die struktuuranalise word die oppervlaktestruktuur bepaal en daarna die semantiese inhoud. Die kolon, wat uit ' $n$ verbale en ' $n$ nominale deel bestaan, vorm ' $n$ linguistiese eenheid en die 
onderlinge verhouding tussen die verskillende kola asook die struktuur van 'n perikoop word deur middel van sintaktiese kriteria bepaal. Volgens die oppervlaktestruktuur blyk dit hoe die skrywer sy boodskap wou aanbied. Die oppervlaktestruktuur is van groot waarde vir die semantiese inligting. Die struktuur moet ontleed word sodat die inhoud verstaan kan word. ${ }^{46}$ Om sy doel te bereik, het Prinsloo in die boek oor Joël met elke woord sy sinsnede erns gemaak. Herhaling van woorde, die metrum, woorspel, verskillende stylsoorte, ensovoorts, is deeglik ondersoek. Aan die einde heg elke perikoop mooi en die boodskap van die geheel en sy onderdele blyk duidelik. Netjies, baie netjies toon hy aan hoe die perikope trapsgewys en klimakties met mekaar skakel en hoe elke passasie 'n progressie met die vorige vertoon. Feitlik elke perikoop gryp deur herhaling van woorde en frases of na 'n vorige perikoop terug of vorentoe na ' $n$ volgende een. ${ }^{47}$ Hierdie eenheidsvisie verkry hy deur sy eksegetiese metode. Hy sê ook van die boek Rut dat dit 'n fyn kunswerk is. Doelbewus het die skrywer sowel die kleinere eenhede as die geheel kunstig en sistematies opgebou. Indien ons nou die boek wil verstaan, is dit uiters noodsaaklik om die struktuur en die opbou van die boek te verstaan. Die "beste kontroleerbare manier om die struktuur te bepaal, is om uit te gaan van objektiewe grammatikale beginsels". ${ }^{48}$ 'n Mens kan sê dat Prinsloo op 'n empiriese, objektiewe, toetsbare manier die boodskap van 'n boek wil bepaal.

Getrou aan die gees van die departement word historiese vrae egter nie verwaarloos nie. Prinsloo beklemtoon voortdurend dat eksegese nie a-histories beoefen moet word nie. Die Ou Testament het tog nie persklaar uit die hemel geval nie, maar het 'n lang en ingewikkelde proses deurloop. Dit spreek dus vanself dat "'n volledige eksegetiese model ook histories-kritiese vrae sal vra". ${ }^{49}$ Prinsloo pleit vir 'n komplementêre eksegetiese model waarin die historiese dimensie ook ' $n$ plek sal hê. En tog beklee die historiese vraagstelling maar 'n mindere rol. Alle historiese vrae is aan die finale teks ondergeskik gestel. Aan die deur van die historiese kritiek word die klag gelê dat die teks in sy eindgestalte alte dikwels verwaarloos is. Histories-kritiese omgang met die teks het ook getoon dat diakroniese gegewens alte maklik van buite af in die teks ingedra word. So byvoorbeeld kan 'n "hipoteties-gerekonstrueerde" beeld van die geskiedenis die "subjektiewe bril" word aan die hand waarvan die teks gelees word. Alhoewel 'n teks se historiese konteks baie belangrik is, moet van historiese vrae afgestap word indien die teks geen sodanige inligting verskaf nie. lemand het eenmaal gesê dat al wat die historikus nodig het, is ' $n$ dokument en verbeelding. Met historiese verbeelding moet die verlede gerekonstrueer word. Vir Prinsloo met sy bepaalde kyk op die teks en sy objektiewe en toetsbare metode is so iets 
onmoontlik. Net daardie historiese inligting wat as't ware objektief voorhande is, kan aangewend word. Verder vorm hierdie vrae nie selfstandige groothede nie, maar word slegs binne die "raamwerk en na aanleiding van die sinchroniese studie" aan die orde gestel. Aan die finale teks moet alle diakroniese vrae beoordeel word. Die historiese dimensie vorm bepaald nie die essensie van die eksegetiese proses nie, maar vervul hoogstens ' $n$ hulpfunksie. Alle "historiese fasette" is volgens Prinsloo "slegs ' $n$ hulp" in die poging om die "finale teks beter te verstaan". ${ }^{50}$

Dateringskwessies kom gevolglik min by Prinsloo voor. Interessant is dat wanneer hy vir die eerste keer oor die datering van die boek Joël praat, doen hy dit in ' $n$ voetnoot. ${ }^{51}$ Met hierdie byna terloopse verwysing wou hy die onnodigheid daarvan beklemtoon dat dateringsvraagstukke eers afgehandel moes word alvorens ' $n$ teks verstaan kan word. Prinsloo wou dus doelbewus nie dat sy werk oor Joël in historiese $k$ wessies moes opgaan nie. Verstaan van 'n teks is inderdaad nie afhanklik van die datering daarvan nie. Natuurlik maak Prinsloo ook historiese opmerkings, maar dit kom nie veel voor nie en dit vorm nie die wese van sy werk nie. Hierdie negatiewe siening is deels te wyte aan die navorsingsresultate waartoe hy in verband met die datering van Joël gekom het. ${ }^{52}$ Hy dui aan dat navorsers hierdie profeet en sy boek tussen die tweede en die negende eeu voor Christus dateer. ' $n$ Periode van sewe eeue is vir Prinsloo onaanvaarbaar. Al het elke geleerde met selfvertroue die geldigheid van sy siening verduidelik, het dit op Prinsloo weinig indruk gemaak. Volgens hom beklemtoon dit net "the relativity and subjectivity of attempts at dating the book". ${ }^{53}$ Vooropgestelde idees het 'n baie groter rol in die datering van Joël gespeel as wat sommige geleerdes sal wil erken. ${ }^{54}$ Prinsloo is baie gedag teen sieninge wat "oversubjectively" aan die boek gekoppel word55 en datering "(which) depends on the presuppositions of the particular exegete". ${ }^{56}$ Dit beteken nou hoegenaamd nie dat die datering nie belangrik is nie. Hy vind dit ' $n$ "useful instrument" om 'n teks te verstaan. Onontkombaar is die feit dat die datering van Joël oor ' $n$ tydperk van sewe eeue geplaas word en dat dit 'n onbegonne taak is om die boek bloot op grond van sy inhoud te dateer. Dit beteken nie ' $n$ doelbewuste onhistoriese lees van die teks nie, maar slegs die erkenning dat die datering van die boek ' $n$ onmoontlikheid is en daarom ook hoegenaamd nie die fokuspunt van die eksegeet moet vorm nie. ${ }^{57}$ Prinsloo maak dus nie 'n punt vir 'n bepaalde tydperk uit nie: “... dit lyk sinneloos om by die horde dateringsvoorstelle nog 'n (subjektiewe!) poging by te voeg". 58

Hooftaak van die Ou-Testamentikus is dus veel eerder om deur middel van immanente eksegese die teologie of die boodskap van 'n bepaalde gedeelte vas te stel. Onder "teologie" verstaan hy "what the 
book ... tells us about Yahweh". 59 Teologiese besigwees, beteken die sistematisering van dit wat die Ou Testament oor Jahwe sê. ${ }^{60}$ Hoe die Ou-Testamentikus sy sistematiseringstaak moet uitvoer, is 'n moeilike probleem. Daar bestaan reeds soveel pogings, maar ten spyte daarvan heers nog soveel onsekerheid. Ons kan selfs van 'n krisis in verband met die basiese sake aangaande die skryf van 'n teologie van die Ou Testament praat. Een ligpunt is dat ons uit die geskiedenis van Ou-Testamentiese teologieë kan leer watter weë onbegaanbaar is en ons nêrens gaan bring nie en watter met vrug bewandel kan word. ${ }^{61}$ So kan ons vandag nie meer van 'n een bepaalde teologie praat nie, is die sistematisering van die stof rondom 'n "Mitte" nie meer haalbaar nie, lei die beklemtoning van een bepaalde tema tot die onderbeklemtoning van ander en moet ' $n$ mens jou weg vind tussen ' $n$ eensydige of a-historiese fokus op die kanon in sy finale gestalte en 'n oorkritiese benadering waarin die eenheid verlore gaan. Om uit hierdie doodloopstraat te kom, stel Prinsloo ' $n$ belangrike beginpunt voor: Ons moet eers die teologie van elke afsonderlike boek of ' $n$ groep eenderse geskrifte in die Ou Testament bepaal. ${ }^{62}$ Eers wanneer elke afsonderlike geskrif of groep geskrifte ten opsigte van hulle teologieë bestudeer is, is 'n "sintese" moontlik. ${ }^{63}$ Prinsloo is onseker of so ' $n$ sintese wel prakties uitvoerbaar of wenslik is, maar voordat ' $n$ mens daarby kom, is die belangrikste dat met die teologie van die kleinste eenheid, die enkele Ou-Testamentiese boek, begin word. Eers daarna kan oor die moontlikheid van 'n sintese besin word. Prinsloo herinner in hierdie verband sterk aan die teologie van Gerhard von Rad wat ook met die kleinste eenheid, die credo, begin en vandaar verder werk. Een belangrike verskil is egter dat Prinsloo nie met 'n paar verse soos in die geval van die credo wil begin nie, maar met ' $n$ boek. En hierdie boek word nie literêr-krities "verklein" nie, maar bestudeer soos dit tans daar uitsien: "The text as we have it today is the object of study." 64

Prinsloo maak ' $n$ ander belangrike opmerking: Die verskille tussen die Ou-Testamentiese geskrifte moet nie weggeredeneer word nie. Ons moet aanvaar dat verskillende teologieë, wat soms radikaal van mekaar kan verskil, in die Ou Testament voorkom. Ons moet die verskillende geskrifte in die Ou Testament soos ' $n$ versameling skilderye van dieselfde landskap beskou. Elkeen interpreteer die werklikheid op sy eie en daarom is daar verskillende skilderye van dieselfde landskap. Geen poging moet nou aangewend word om die verskillende vertolkings tot ' $n$ eenheid te versmelt nie, maar elkeen moet afsonderlik waardeer word. So pleit Prinsloo dan dat ons die verskeidenheid sal respekteer. En sy beskouing dat die onderskeie boeke eers afsonderlik in hulle finale gestalte bestudeer sal word, bied ook 'n manier waarop met die verskille omgegaan 
moet word: In plaas daarvan om die verskeidenheid te ontken of fundamentalisties te probeer verdoesel, moet die verbande asook die spanninge tussen die verskillende teologieë aangetoon en fyn op die funksie daarvan gelet word. ${ }^{65}$ Deur dit te doen sal elke afsonderlike boek se teologie beter verstaan word.

Samevattend kan ons sê dat Prinsloo van die teks in sy eindgestalte uitgaan, die betekenis met behulp van immanente eksegese wil ontsluit, net in terme van die eindteks aan historiese vrae aandag skenk, 'n Ou-Testamentiese teologie as die eindpunt van eksegetiese werk beskou en by die teologie van die afsonderlike Ou-Testamentiese geskrifte wil begin om 'n moontlike teologie van die Ou Testament te skryf.

\section{W Vosloo}

William Vosloo is op 7 April 1934 gebore. Voordat hy met teologiese studie begin het, het hy eers 'n draai in die finansiële wêreld gemaak. In 1967 het hy met teologiese studie begin en was ook ' $n$ uitstekende student wat alle grade met lof geslaag het. Voordat Vosloo in 1980 na die Universiteit van Pretoria beroep is, was hy vir baie jare aan Unisa verbonde. Vosloo se leeropdrag is Bybelkunde, maar hy is ook aktief by die opleiding van predikante betrokke. Ter illustrasie van sy bydrae fokus ons hieronder veral op sy werk oor die aartsvaders.

Vosloo het ' $n$ eie benadering tot die vak. 'n Mens kan amper sê hy is 'n "sintese" van sowel Van Zyl as Prinsloo. Die rede hiervoor is dat Vosloo aan sowel die historiese benadering tot die teks as die teks in sy finale gestalte volle reg wil laat geskied. Vir hom is die verlede én die hede van die teks belangrik, is die een nie 'n blote funksie van die ander nie en moet elkeen tot sy volle reg kom. Kenmerkend van Vosloo is dat historiese vrae ook by hom in ' $n$ veel ruimer of getemperde historieskritiese konteks teregkom. Hierin word die aard van sy historiese aanvoeling goed geillustreer. ' $n$ Voorbeeld hiervan is die wyse waarop hy die probleem van historisiteit hanteer. In die geval van die aartsvaders is hy van mening dat die ontkenning van die historisiteit tot die ondermyning van die gesag van die Ou Testament kan lei. Volgens hom het die werk van Wellhausen tot ' $n$ voortdurende proses van ontkenning van die aartsvaders se historisiteit aanleiding gegee. Volgens Wellhausen was die aartsvaders niks anders as terugprojeksies van latere outeurs nie en het die aartsvaders nooit werklik bestaan nie. Hierdie gedagtegang het daartoe gelei dat die bestaan van die aartsvaders deur verskillende geleerdes ontken is. Volgens Vosloo is hiermee aangetoon "hoe kwesbaar ' $n$ teologie is wat op historiese positiwisme gebou word". ${ }^{66}$ Alhoewel hy teen die uiterste waak, wil hy ook nie die probleem in 'n eensydige 
histories-fundamentalistiese benadering laat opgaan nie. Hy stel dan baie sterk dat die saak nie op ' $n$ histories-onwetenskaplike voet geplaas moet word nie. Die bestaan van die aartsvaders is nog lank nie bewys wanneer die bronne vroeg gedateer word, ooreenkomste met dokumente in die ou Nabye Ooste aangetoon is of die bronneteorie verkeerd bewys word nie. Belangrik is sy opmerkinge oor die argeologie. In fundamentalistiese kringe word naarstiglik hierna verwys in 'n poging om die historisiteit van die aartsvaders te bewys. Tereg merk Vosloo op dat vele probleme aan so 'n werksmetode gekoppel is. Oor literêre kritiek, wat so dikwels onder die skoot gekom het van diegene wat die historisiteit van die aartsvaders verdedig, het Vosloo ook 'n positiewe woord. Hy vra die vraag of literêre kritiek nie maar ' $n$ ander eerlike poging is om die Skrif te verstaan nie. ${ }^{67}$ Van groot waarde is sy opmerking dat iets van die boodskap verlore gaan indien alles net soos dit daar staan, waar moet wees. Volgens hom het die historisiteit van die aartsvaders vir Israel nie so op die voorgrond gestaan nie. En tog was dit belangrik dat hulle werklik bestaan het. Vir Israel was die aartsvaders die grondleggers van die geloof en daarom het die volk hulle so ingeleef in die aartsvaders. In hulle swakhede het die Israeliet sy eie swakhede ontdek en die hoogtepunte in hulle lewens was die ideaal waarna hy gestreef het. Hierdie aartsvadertradisies was die gemeengoed van elke Israeliet en was dié faktor wat mense aan mekaar gebind het. ${ }^{68}$ Die aartsvadergebeure was deurslaggewend vir die volk se geloof en het op verskeie maniere rigting aan hulle lewens gegee. ${ }^{69} \mathrm{Van}$ weë hierdie inlewing met die gebeure met die aartsvaders is die verhale voortdurend herinterpreteer. In elke tyd is dit so in die geloof geïnterpreteer dat die verhale in hulle huidige konteks ook iets van Israel se geloof in Jahwe en sy geloofstryd weerspieël. In 'n groot mate beliggaam hierdie verhale ook die geloof van Israel oor baie eeue heen. Wanneer dan op die historisiteit van die aartsvaders en die verhale wat van hulle vertel, aangedring word, gaan iets verlore. Vosloo stel dit soos volg: "... hou die gesamentlike ondervindinge en geloof van 'n volk vir my nie meer waarde en sekerheid in as die ondervinding van 'n enkeling nie" ${ }^{\prime \prime}{ }^{70} \mathrm{Met}$ hierdie benadering het Vosloo inderdaad ' $n$ bydrae gemaak om die historisiteitsvraag, wat in ons land nogal baie gevra word, in ' $n$ baie wyer verstaansraamwerk te plaas.

Alhoewel Vosloo ook van die historiese kritiek gebruik maak, sou sy hantering daarvan altyd met die werklikheid van gebeure rekening hou. In sy studie van die aartsvaders gaan hy daarvan uit dat hulle werklik geleef het en dat hulle ook histories ondersoek kan word. Met behulp van die historiese kritiek wil hy die konteks van die aartsvaders vasstel, want kennis hiervan het konsekwensies vir die verstaan van die aartsvaderverhale: "So 'n historiese plasing is noodsaaklik, want om die 
aartsvaders, hulle bewegings, hulle optredes, gebruike, probleme, godsdiens en daarom ook die betekenis van hulle verhouding met hulle God, te kan begryp, is dit noodsaaklik om hulle in hulle historiese milieu te beskou." 71 Vosloo dring egter daarop aan dat alle historiese studie met die aard van die bron (dit is die Ou Testament) rekening moet hou. Alhoewel die $\mathrm{Ou}$ Testament nie ' $\mathrm{n}$ geskiedenisboek is nie, het die dinge wat daarin vermeld word tog in die geskiedenis van die mensdom afgespeel en daarom kan dit ook histories bestudeer word. ${ }^{72}$ Ou-Testamentiese geskiedenis is egter nie ' $n$ geskiedenis in die gewone sin van die woord nie, maar is 'n geskiedenis met ' $n$ boodskap. Hy gebruik ook die benaming "kerugmatiese geskiedenis" en bedoel daarmee "'n predikende geskiedenis, d.w.s. geskiedenis wat 'n boodskap aan die mense wat die geskiedenis belewe en oorvertel het, verkondig het."73 Hierdie vorm van geskiedenis het egter twee baie belangrike kenmerke: Dit vertel van gebeure wat werklik plaasgevind het en tog bevat dit ook ' $n$ boodskap.

Uiters belangrik is dat Vosloo ook die finale teks as vertrekpunt vir sy Ou-Testamentiese studie aanwend. Interessant is egter dat die finale teks in noue samehang met die historiese komponent daarvan beskou moet word. By Prinsloo het die historiese vrae slegs ter sprake gekom indien die teks daartoe aanleiding gegee het en was dit hoogstens 'n funksie van die teks in sy eindgestalte. Historiese bemoeienis speel by hom 'n ondergeskikte rol. Vosloo sien die saak wyer en wil die hele historiese proses laat meespeel in die verstaan. Ook die finale teks het ' $n$ wording en die historiese kritiek het nou eenmaal belangrike bydraes gelewer wat in die verstaan van juis die finale teks tog nie buite rekening gelaat kan word nie. In sy werk oor die aartsvaderbeloftes maak hy ook ruim van die resultate van die historiese kritiek gebruik. So byvoorbeeld weet ons meer van die ontstaanstyd van hierdie beloftes. Gewoonlik word die aartsvadertyd, die vroeë monargie en die ballingskap as moontlike ontstaanstye aangedui. Volgens Vosloo moet ons nie vir een kies nie, maar eerder oog vir die historiese ontwikkeling en die oorleweringshistoriese aspek van hierdie beloftes hê. ${ }^{74}$ In sy studie van hierdie beloftes in hulle finale konteks word "ter wille van perspektief" die relevante resultate van die histories-kritiese navorsing vermeld. ${ }^{75}$

Ten spyte van die belangrikheid van historiese perspektiewe vermeld Vosloo dat een groot leemte mettertyd ontstaan het: "Dit is naamlik die bestudering en analise van die teks soos dit vandag beskikbaar is." 76 Te veel aandag is aan die wording van die teks en die brokstukke waaruit dit bestaan, geskenk en te min aan die geheel van die vertellinge. Indien die finale teks die uitgangspunt vorm, sien hy ook 'n groter moontlikheid om sogenaamde probleme soos doeblette, anakronistiese uitdrukkings, latere byvoegings, ensovoorts, te verklaar. Deur middel van 
ewewigstrukture wil Vosloo die finale teks bestudeer. Dit is belangrik om daarop te let dat net soos in die geval van Prinsloo, strukture essensieel vir die verstaan van 'n teks word. By Vosloo funksioneer egter ' $n$ ander opvatting van strukture. Volgens hom is 'n ewewigstruktuur "die beskrywing van die bou van 'n Skrifdeel wat saamgestel is uit twee komponente van eweredige of oneweredige omvang, maar met parallelle inhoud waardeur 'n balans, hetsy deur ooreenkoms, hetsy deur teenstelling tussen die twee komponente verkry word."77 Elders is hierdie metode met groot vrug gebruik, maar Vosloo was die eerste wat dit in Suid-Afrikaanse Ou-Testamentiese kringe op so 'n grootskaalse en so 'n doelgerigte manier aangewend het. ${ }^{78}$ Vir hom is dit so 'n belangrike werkswyse omdat kennis van die struktuur teologiese afleidings help moontlik maak. Kortom: Struktuur en teologie is nou verbind. Ewewigstrukture werp verder ook lig op die manier waarop die teks gebind is en die funksie van die beloftes binne die huidige konteks. Volgens Vosloo kan sy benadering die spanninge wat so deur die historiese kritiek uitgewys is, verklaar en skep dit 'n eenheidsbeeld van die teks sodat dit moontlik om die funksie van elke sogenaamde byvoeging of doeblet te verstaan en om die onderskeie dele in die lig van die geheel te begryp. ${ }^{79}$

Vosloo se standpunte kan ons soos volg saamvat: Soos Kritzinger en Van Zyl het hy baie van die geskiedenis gemaak. Nooit kan die resultate van die historiese kritiek geignoreer word nie. Enige studie van die Ou Testament sal indringend hiermee moet worstel. Aan die ander kant moet die finale teks as uitgangspunt van enige studie dien. Veel klem word op ewewigstrukture gelê omdat dit teologiese afleidings moontlik maak en afdoende antwoorde op belangrike vrae verskaf.

\section{Slot}

Die afgelope vyftig jaar het hierdie vier persone 'n grondslag vir die beoefening van die Ou-Testamentiese wetenskap gelê wat akademiese respek afdwing. As 'n reaksie op die Du Plessisstryd kon 'n fundamentalistiese departement ontwikkel het wat vir kritiek wegskram, apologeties te werk gaan en die perspektief op die Ou Testament verskraal. Gelukkig het dit nie gebeur nie, maar is 'n akademiese tradisie ontwikkel waarvolgens krities met die Ou Testament omgegaan kon word sonder dat die gesag daarvan in gedrang gekom het; daar is so met die historiese kritiek omgegaan dat dit die verkondiging kon dien; 'n werksatmosfeer is geskep waarin geloof en wetenskap nie op 'n gespanne voet verkeer het nie. ' $n$ Baie belangrike kenmerk van die bogenoemde dosente is behalwe die klem op geskiedenis, die fokus op die eindgestalte van die teks sowel as die beklemtoning van die teologie of die boodskap van die Ou Testament. 


\section{NOTAS}

1. J H Kritzinger, "Outobiografie", Deo Gloria (1965), 2-5.

2. J H Kritzinger, Die profesie van Joël, Amsterdam 1935, Voorwoord.

3. Kritzinger, a.w., Stellings.

4. Kritzinger, a.w., Voorwoord.

5. Kritzinger, a.w., Stellings.

6. J H Kritzinger, "Outobiografie", Deo Gloria (1965), 2-3.

7. Kritzinger, a.w., 4-5.

8. E P Groenewald, "Prof J H Kritzinger tree uit", NGTT 7/1 (1965), 4.

9. Groenewald, a.w.

10. J H Kritzinger, "Outobiografie", Deo Gloria (1965), 5.

11. F J M Potgieter, "Van die redaksie", NGTT 6/3 (1965), 130.

12. J H Kritzinger, "Outobiografie", Deo Gloria (1965), 4.

13. E P Groenewald, "Prof J H Kritzinger tree uit", NGTT 7/1 (1965), 4.

14. J H Kritzinger, Die skeppingsdae in Genesis, Pretoria 1939, 9-10.

15. A.w., 3.

16. A.w., 8.

17. A.w., 7.

18. J H Kritzinger, Die profesie van Joël, Amsterdam 1935, I.

19. A.W., V-VI.

20. A.w., VI-XXI; J H Kritzinger, "Joël" in: Die Bybel met verklarende aantekeninge, Kaapstad 1958, 1940.

21. J H Kritzinger, Die profesie van Joël", Amsterdam 1935, XIII.

22. A.w., XXXIII.

23. A.w., 92-97; J H Kritzinger, "Joël", 1943.

24. J H Kritzinger, Die profesie van Joël, Amsterdam 1935, 92.

25. J H Kritzinger, "Joèr", 1947.

26. A.W.

27. A H van $\mathrm{Zyl}$, Gods Woord in mensetaal, Deel I, Durban 1975, 102.

28. A.W., 100.

29. A.W., 101.

30. A.w., $102-106$.

31. A.w., $108-110$.

32. A.w., 110-111.

33. A.W., 100, 111.

34. A.W., 111-115.

35. A.w., 115.

36. W S Prinsloo, "Die boek Joël: verleentheid of geleentheid?", NGTT 24/3 (1983), 255-256; W S Prinsloo, "Die boek Joël" in: J J Burden en W S Prinsloo, Tweegesprek met God, Kaapstad 1987, 234.

37. W S Prinsloo, "Die boek Joël: verleentheid of geleentheid?", NGTT 24/3 (1983), 255-256; The theology of the book of Joel, Berlin 1985, 2-5; "Die boek Joël" in: J J Burden en W S Prinsioo, Tweegesprek met God, Kaapstad 1987, 235-237.

38. B S Childs, Introduction to the Old Testament as Scripture, London 1983, 392; W S Prinsloo, "Die boek Joël: verleentheid of geleentheid?", NGTT 24/3 (1983), 263.

39. A.W., 258.

40. A.W.

41. W S Prinsloo, Isaiah 14:12 - 15 - Humiliation, hubris, humiliation", ZAW 93 (1981), 432-433. 
42. W S Prinsloo, "Die metodiek van eksegese: 'n Diskussie", NGTT 20/3 (1979), 210.

43. W S Prinsloo, Van kateder tot kansel, Pretoria 1984, 4.

44. A.w.

45. W S Prinsloo, "Die metodiek van eksegese: 'n Diskussie", NGTT 20/3 (1979), $210-211$.

46. W S Prinsloo, "The function of Ruth in the book Ruth", OTWSA 20/21 (1977/78), 110-129; "The theology of the book of Ruth", VT 30 (1980), 331.

47. W S Prinsloo, "Die boek Joël", in: J J Burden en W S Prinsloo, Tweegesprek met God, Kaapstad 1987, 231-234; The theology of the book of Joel, Berlin 1985. 122- 127.

48. W S Prinsloo, Die boek Rut, Kaapstad 1982,3

49. W S Prinsloo, Die Ou Testament, 'n verouderde boek? Enkele gedagtes na aanleiding van Psalm 15. Pretoria 1987, 4.

50. W S Prinsloo, Van kateder tot kansel, Pretoria 1984, 4.

51. W S Prinsloo, The theology of the book of Joel, Berlin 1985, $35 \mathrm{n} 40$.

52. A.w., 5-8: "Die boek Joël: verleentheid of geleentheid?", NGTT 24/3 (1983), $255-263$.

53. W S Prinsloo, The theology of the book of Joel, Berlin 1985, 109.

54. A.W., 92.

55. A.W., 40-41, n 4 .

56. A.w., 35, $\mathrm{n} 43$.

57. A.W., 92.

58. W S Prinsloo, "Die boek Joël: verleentheid of geleentheid?", NGTT 24/3 (1983), 262.

59. W S Prinsloo, The theology of the book of Joel, Berlin 1985, 2.

60. W S Prinsloo, "Ou Testament teologie vandag", in: W S Prinsloo en W Vosloo, Ou Testament teologie: gister, vandag en môre, Pretoria 1987, 40.

61. A.W., $29-46$.

62. Vgl W S Prinsloo, "Die boodskap van die boek Habakuk", NGTT 20/2 (1979), 146-151; "The theology of the book of Ruth", VT 30 (1980), 330-341; Van kateder tot kansel, Pretoria 1984; The theology of the books of Joel, Berlin 1985.

63. W S Prinsloo, "Ou Testament teologie vandag" in: W S Prinsloo en W Vosloo, Ou Testement teologie: gister, vandag en móre, Pretoria 1987, 39.

64. W S Prinsloo, The theology of the book of Joel, Berlin 1985, 2.

65. W S Prinsloo, "Ou Testament teologie vandag", in: W S Prinsloo en W Vosloo Ou Testament teologie: gister, vandag en móre, Pretoria 1987, 39.

66. W Vosloo, "Die historiese betroubaarheid van die aartsvadervertellinge", Skrif en kerk 3/1 (1982), 46

67. A.w., 51.

68. W Vosloo, "Die aartsvaders", in: A H van Zyl (et a/l, /srae/ en sy bure, Durban 1977. 62.

69. A.w. 38 .

70. W Vosloo, "Die historiese betroubaarheid van die aartsvadervertellinge", Skrif en Kerk 3/1 (1982), 54

72. W Vosloo, Méér as net 'n storie, Pretoria 1986, 1.

73. W Vosloo, "Die voorgeskiedenis" in: A H van Zyl (et al), Israel en sy bure, Durban 1977, 1.

71. W Vosloo, "Die aartsvaders" in: A H van Zyl (et all, Israe/ en sy bure, Durban 1977, 38.

74. W Vosloo, Die Abrahamsbeloftes in die Abrahamsvertellinge in Genesis. 'n Literêre en teologiese analise, Pretoria 1978, 14 (ongepubliseerde DD-proefskrif) 
75. A.w., 18, 47-96.

76. A.W., 16.

77. A.W. 31.

78. W Vosloo, "Balance structures in the Old Testament", Theologica Evangelica $12 / 1,48-60$.

79. W Vosloo, Die Abrahamsbeloftes in die Abrahamsvertellinge in Genesis. 'n Literêre en teologiese analise, Pretoria 1978, 94-96. 